\title{
Knowledge, Attitudes, and Practices of Leptospirosis in Catbalogan City, Samar, Philippines
}

\author{
Charmaine R. Quina, Joseph U. Almazan*, Juniel B. Tagarino \\ Clinical Instructors, College of Nursing and Health Sciences, Samar State University, Philippines \\ *Corresponding author: almazanjoseph93@yahoo.com
}

Received February 09, 2014; Revised April 23, 2014; Accepted May 03, 2014

\begin{abstract}
Leptospirosis is a global bacterial infection that can kill millions of people through contact of mucous membranes or broken skin with water moist soil contaminated with the urine of infected animals. This study determines Knowledge, Attitudes, and Practices of Leptospirosis among barangay residents, health workers, and barangay officials in Catbalogan, City Samar. The study employed the analytical research design, analysis as to any differences in the level of knowledge and extent of practice of prevention and control strategies were made with the use of T-test. There were 187 respondents of the study which included the health workers, barangay officials, and selected residents of six barangays in Catbalogan City. Findings revealed that information dissemination through mass media (TV) is the number one preventive and control strategy to avoid leptospirosis and this could be one of the information that they could share to members of the family and friends. The common prevention and control strategies practiced by the three groups of respondents were to maintain cleanliness on the surrounding and to keep good hygiene. The health workers and barangay officials "frequently practiced" them while the barangay residents "always practiced" them. The Barangay health workers in the RHU and local government unit must have proper information dissemination regarding Leptospirosis, it emphasized environmental sanitation, teaching about the proper safety precautions and develops the interest of the respondents. Moreover, another study is conducted in other city/municipality to ascertain the level of awareness and knowledge of the community residents, thereby validating the findings of this study.
\end{abstract}

Keywords: leptospirosis, leptospirosis knowledge, leptospirosis attitudes, leptospirosis

Cite This Article: Charmaine R. Quina, Joseph U. Almazan, and Juniel B. Tagarino, "Knowledge, Attitudes, and Practices of Leptospirosis in Catbalogan City, Samar, Philippines.” American Journal of Public Health Research, vol. 2, no. 3 (2014): 91-98. doi: 10.12691/ajphr-2-3-5.

\section{Introduction}

Leptospirosis is a global bacterial infection caused by Leptospira species, a spiral shaped bacteria that live in both domestic and wild animals particularly rats [1]. Millions of humans become infected each year through contact with food, and water, or contaminated with urine from these infected animals [2]. Thus, swimming or wading in contaminated water becomes particularly hazardous. The bacteria usually enters the body through a broken, grazed or cut skin, especially on the extremities, and sometimes through the linings of the mouth, nose and eyes [3]. In modern years, leptospirosis has been categorized as a reemerging infectious disease particularly in tropical/subtropical countries [4], where environmental and socioeconomic conditions for its transmission were particularly favorable [5].

In humans, Leptospirosis can cause a wide range of symptoms, including: High fever Headache, Rash, Diarrhea, Abdominal Pain, Muscle aches, Vomiting, Jaundice (yellow skin and eyes) Red eyes, Chills. Worst scenario, some infected persons may have no symptoms at all. The duration of person's exposure to a contaminated source and becoming sick is 2 days to more than 4 weeks. The disease usually begins abruptly with fever and other symptoms.The disease lasts from days to 3 weeks or longer [6]. Since the disease last more than weeks, the cases ranges from 0.1 to 1 per 100000 per year in temperate climates to 10 or more per 100000 per year in the humid tropics [7]. In outbreaks increases to 100 or more per 100000 may be infected [8].

In Asia, Seasonal outbreaks of the disease have been reported in northern Thailand and Gujurat state of India following flooding and heavy rain. Most important outbreaks in South-East Asia were reported in the past due to cyclone in Orrisa (1999), flooding in Jakarta (2002), Mumbai (2005) and in Sri Lanka (2008) [21].

Heavy rainfall and flooding increase the incidence of leptospirosis. In 2011 cases of leptospirosis associated with heavy monsoon rains and typhoons were reported in Philippines [9]. Thailand [10]. Moreover, Asia Pacific region, mainly in the developing countries, leptospirosis is mostly a water-borne disease. Unless implementation to minimize exposure is assertively implemented, the current global climate change will further aggravate the extent of the disease. Even though trends indicate successful control of leptospirosis in a few areas, there is no clear proof that the disease has decreased in the last decade [11]. 
Furthermore, like any other developing countries, the disease is endemic in the Philippines and the number of cases peak during the rainy months of the year. Outbreaks have been associated with wading in flood waters. An average of 680 Leptospirosis cases and 40 deaths from the disease are reported every year. A Leptospirosis outbreak was declared by the Department of Health two weeks after the heavy rainfall brought about by typhoon Ondoy (Ketsana) last September 26, 2009. As of November of the same year a total of 2,292 suspected cases of Leptospirosis reported with 178 deaths (8\%) in 15 hospitals in Metro Manila. In the Luzon region (Regions I, III, IV-A and Cordillera Autonomous Region), 1090 cases and 71 deaths were recorded. In the Eastern Visayas region, that was hit by tropical depression "Ramon” in March 2011 which resulted to flooding in several areas in Leyte, the DOH VIII regional office recorded a total of 67 suspected cases out of which 8 died and 8 were also found to be positive for Leptospirosis Rapid Test. The recorded cases came from the different cities and towns of Samar and Leyte wherein Tacloban City and Palo Leyte reported a higher number of suspected cases of 12 and 10 correspondingly [12].

Determining the prevailing knowledge, perceptions, attitudes and practices toward preventing Leptospirosis infection and understanding the underlying is critical to planning public health interventions tailored to aim populations [13]. In Catbalogan City, no study conducted on examining barangay residents, and health workers and barangay officials knowledge, attitudes and practices towards Leptospirosis have been conducted. Although advocacy programs against Leptospirosis prevention and control have been launched in the endemic areas, an annual outbreak of leptospirosis still occurs. Hence, the researchers were motivated to conduct this study.

\subsection{Research Objective}

This investigation was undertaken to determine Knowledge, Attitudes, and Practices of Leptospirosis among barangay residents, health workers and barangay officials.

\section{Methodology}

A cross sectional study was adopted for this investigation among the different types of descriptive studies. This study design is appropriate as the main objective of this investigation was to assess Knowledge, Attitudes, and Practices of Leptospirosis among barangay residents, health workers and barangay officials.

\subsection{Participants}

There were 187 respondents of the study which included the health workers and barangay officials and selected residents of six barangays in Catbalogan City. The six barangays were: Barangay Munoz, Barangay 1, Barangay 7, Barangay Canlapwas, Barangay 13, and Barangay Guindapunan. One hundred twenty (120) barangay residents were chosen and who were at least 18 years of age and were available at the time of survey. Total number of households in the six barangays covered in the study is estimated to be 12,000 .

\subsection{Measures}

A survey questionnaire was used to gather the data consisting of: Part 1 inquires about the socio demographic profile of the two groups of respondents on age, occupation, educational attainment and total family income. Part II consists of three subparts: II A consists of our statements per category which inquires about the prevailing knowledge of the as to the causative organism, disease transmission, common signs and symptoms and prevention and control practices regarding Leptospirosis. Part II B determines the prevailing attitude of the respondents wherein they were asked about their sources of information on Leptospirosis and inquires about their reaction to the information and other attitudinal issues. A four-point Likert scale was used to answer the other attitudinal issues listed with 4 corresponding to highly concerned, 3- moderately concerned, 2- least concerned, and 1 for not concerned at all. Part IIC consists of ten activity statements from which respondents were asked to choose from terms of what they thought are the appropriate prevention and control practices on Leptospirosis. In addition, this sub part inquires about the extent of practice with the use of a four-point likert scale wherein 4 corresponds to always practiced, 3 - frequently practiced, 2- moderately practiced and 1 for seldom practiced.

\subsection{Ethical consideration}

The investigators send an approval letters to the Ethics Committee on Local Government of Catbalogan City before conducting the investigation and was approved. The Confidentiality of information and anonymity of the respondents were maintained by using only code number instead the name of the respondents.

\subsection{Data Analysis}

The study employed the analytical research design to determine the prevailing knowledge, attitude and prevention and control practices regarding Leptospirosis of the three groups of respondents, namely; the health workers and barangay officials and barangay residents of Catbalogan City, Western Samar. The demographic characteristics of respondents as to age, occupation, educational attainment, and total family income were first described utilizing frequency table, percentages, and mean scores. Mean scores were also used to measure the level of knowledge, attitudes and practices on Leptospirosis. Analysis as to any differences in the level of knowledge and extent of practice of prevention and control strategies shall be made with the use of T-test. This will be analyzed analyzed using SPSS, version 19.

\section{Results}

Table 1.1 shows the prevailing level of knowledge of the health workers and barangay officials on leptospirosis along etiology or causative organism. From the table, it can be noted that this group of respondents showed that majority of them were affirmative on the indicator numbers 2 and 1, stating: "leptospirosis is caused by a Bacteria;" and Leptospirosis is caused by a virus," where 
six or 88.06 percent and 36 or 88.06 percent signified, respectively. In indicator numbers 4 and 3, a good number of them signified negatively which corresponded to the following: "the microorganism that causes the disease is a parasite or work," with 53 or 79.10 percent; and "leptospirosis is caused by dirt and dust," with 52 or 77.62 percent.

Table 1.1. Level of Knowledge on Leptospirosis Among Health Workers and Barangay Officials in the Aspect of Causative Organism

\begin{tabular}{|c|c|c|c|c|c|c|}
\hline \multirow{2}{*}{ Indicators } & \multicolumn{2}{|c|}{ Yes } & \multicolumn{3}{c|}{ No } & \multicolumn{2}{c|}{ Total } \\
\cline { 2 - 7 } & Frequency & Percentage & Frequency & Percentage & Frequency & Percentage \\
\hline Leptospirosis is caused by a virus. & 36 & 53.73 & 31 & 46.27 & 67 & 100.00 \\
\hline Leptospirosis is caused by a bacteria. & 59 & 88.06 & 8 & 11.94 & 67 & 100.00 \\
\hline Leptospirosis is caused by dirt and dust. & 15 & 22.38 & 52 & 77.62 & 67 & 100.00 \\
\hline The microorganism that causes the disease is a parasite or worm. & 14 & 20.90 & 53 & 79.10 & 67 & 100.00 \\
\hline
\end{tabular}

Table 1.2 provides the information on the prevailing level of knowledge of the barangay residents on leptospirosis along etiology or causative organism. From the table, it can be seen that this majority respondents were affirmative on the indicator 2 "leptospirosis is caused

by a bacteria,” with 104 or 87.39 percent. On the other hand, the barangay residents' majority negatively responded on indicator number 3 stating: "leptospirosis is caused by dirt and dust," with 67 or 56.78 percent.

Table 1.2. Level of Knowledge on Leptospirosis among Barangay Residents in the Aspect of Causative Organism

\begin{tabular}{|c|c|c|c|c|c|c|}
\hline \multirow{2}{*}{ Indicators } & \multicolumn{2}{|c|}{ Yes } & \multicolumn{2}{|c|}{ No } & \multicolumn{2}{|c|}{ Total } \\
\hline & Frequency & Percentage & Frequency & Percentage & Frequency & Percentage \\
\hline Leptospirosis is caused by a virus. & 72 & 60.50 & 47 & 39.50 & 119 & 100.00 \\
\hline Leptospirosis is caused by a bacteria. & 104 & 87.39 & 15 & 12,61 & 119 & 100.00 \\
\hline Leptospirosis is caused by dirt and dust. & 51 & 43.22 & 67 & 56.78 & 118 & 100.00 \\
\hline The microorganism that causes the disease is a parasite or worm. & 52 & 44.44 & 65 & 55.56 & 117 & 100.00 \\
\hline
\end{tabular}

Table 1.3 shown prevailing level of knowledge on leptospirosis among health workers and barangay officials in the aspect of disease transmission, it can be gleaned that majority of respondents were affirmative on indicator number 4 "the high risk of being inflected by the disease is during flooding season," with 56 or 83.58 percent; and negatively indicator which has the highest was 50 or 74.63 percent.

Table 1.3. Level of Knowledge on Leptospirosis Among Health Workers and Barangay Officials in the Aspect of Disease Transmission

\begin{tabular}{|c|c|c|c|c|c|c|}
\hline \multirow{2}{*}{ Indicators } & \multicolumn{2}{|c|}{ Yes } & \multicolumn{2}{|c|}{ No } & \multicolumn{2}{|c|}{ Total } \\
\hline & Frequency & Percentage & Frequency & Percentage & Frequency & Percentage \\
\hline $\begin{array}{l}\text { Leptospirosis organism enters the body through the cuts and cracks } \\
\text { of the skin of the feet and hands }\end{array}$ & 51 & 76.12 & 16 & 23.88 & 67 & 100.00 \\
\hline $\begin{array}{l}\text { The organism enters the body through the saliva of the rat that } \\
\text { bitten the victim }\end{array}$ & 30 & 44.78 & 37 & 55.22 & 67 & 100.00 \\
\hline The disease can be transmitted through the air & 17 & 25.37 & 50 & 74.63 & 67 & 100.00 \\
\hline $\begin{array}{l}\text { The high risk of being inflected by the disease is during flooding } \\
\text { season }\end{array}$ & 56 & 83.58 & 11 & 16.42 & 67 & 100.00 \\
\hline
\end{tabular}

Table 1.4 presents the prevailing level of knowledge of the barangay residents on the disease transmission of leptospirosis. The table shows that this group of respondents were highest affirmative on the indicator 1 "Leptospirosis organism enters the body through the cuts

and cracks of the skin of the feet and hands," with 103 or 85.80 percent. In the indicator number 3 stating: "The disease can be transmitted through the air," with 81 or 69.83 percent, this majority of respondents were highest negative response to it.

Table 1.4. Level of Knowledge on Leptospirosis among Barangay Residents in the Aspect of Disease Transmission

\begin{tabular}{|c|c|c|c|c|c|c|}
\hline \multirow{2}{*}{ Indicators } & \multicolumn{2}{|c|}{ Yes } & \multicolumn{3}{|c|}{ No } & \multicolumn{2}{c|}{ Total } \\
\cline { 2 - 7 } & Frequency & Percentage & Frequency & Percentage & Frequency & Percentage \\
\hline $\begin{array}{c}\text { Leptospirosis organism enters the body through the cuts and cracks } \\
\text { of the skin of the feet and hands. }\end{array}$ & 103 & 85.80 & 17 & 14.20 & 120 & 100.00 \\
\hline $\begin{array}{c}\text { The organism enters the body through the saliva of the rat that } \\
\text { bitten the victim }\end{array}$ & 63 & 52.50 & 57 & 47.50 & 120 & 100.00 \\
\hline The disease can be transmitted through the air. & 35 & 30.17 & 81 & 69.83 & 116 & 100.00 \\
\hline $\begin{array}{c}\text { The high risk of being inflected by the disease is during flooding } \\
\text { season }\end{array}$ & 99 & 83.20 & 20 & 16.80 & 119 & 100.00 \\
\hline
\end{tabular}

Table 1.5 reveals the prevailing level of knowledge of the health workers and barangay officials on leptospirosis in the area of common signs and symptoms. The table reveals that this group of respondent gave affirmative evaluation on indicators number 2, 3, and 4 stating: "An infected person will develop fever, body and muscle pains and, yellowing of the skin and eyes," with 51 or 76.12 percent; "An infected person will primarily manifest allergic reactions like itchiness and redness of affected skin," with 39 or 58.21 percent; and "An infected person may suffer fever and bleeding in the nose and stomach," with 37 or 55.22 percent. 
Table 1.5. Level of Knowledge on Leptospirosis among Health Workers and Barangay Officials in the Aspect of Common Signs and Symptoms

\begin{tabular}{|c|c|c|c|c|c|c|}
\hline \multirow{2}{*}{ Indicators } & \multicolumn{2}{|c|}{ Yes } & \multicolumn{2}{|c|}{ No } & \multicolumn{2}{|c|}{ Total } \\
\hline & Frequency & Percentage & Frequency & Percentage & Frequency & Percentage \\
\hline $\begin{array}{l}\text { An infected person will exhibit rat-like behavior like repetitious } \\
\text { smelling for food sources. }\end{array}$ & 16 & 23.88 & 51 & 76.12 & 67 & 100.00 \\
\hline $\begin{array}{l}\text { An infected person will develop fever, body and muscle pains and, } \\
\text { yellowing of the skin and eyes. }\end{array}$ & 51 & 76.12 & 16 & 23.88 & 67 & 100.00 \\
\hline $\begin{array}{l}\text { An infected person may suffer fever and bleeding in the nose and } \\
\text { stomach }\end{array}$ & 37 & 55.22 & 30 & 44.78 & 67 & 100.00 \\
\hline $\begin{array}{l}\text { An infected person will primarily manifest allergic reactions like } \\
\text { itchiness and redness of affected skin. }\end{array}$ & 39 & 58.21 & 28 & 41.79 & 67 & 100.00 \\
\hline
\end{tabular}

Table 1.6 reveals the prevailing knowledge of the barangay residents on the common signs and symptoms of leptospirosis. The table revealed that this group of respondents affirmatively assessed three indicators, numbers 2, 4 and 3 corresponding to the statements stating: "An infected person will develop fever, body and muscle

pains and, yellowing of the skin and eyes," with 103 or 866.60 percent; “An infected person will primarily manifest allergic reactions like itchiness and redness of affected skin," with 101 or 84.20 percent, and “An infected person may suffer fever and bleeding in the nose and stomach,” with 67 or 58.30 percent.

Table 1.6. Level of Knowledge on Leptospirosis among Barangay Residents in the Aspect of Common Signs and Symptoms

\begin{tabular}{|c|c|c|c|c|c|c|}
\hline Indicators & \multicolumn{2}{|c|}{ Yes } & \multicolumn{3}{c|}{ No } & \multicolumn{2}{c|}{ Total } \\
\cline { 2 - 7 } & Frequency & Percentage & Frequency & Percentage & Frequency & Percentage \\
\hline $\begin{array}{c}\text { An infected person will exhibit rat-like behavior like repetitious } \\
\text { smelling for food sources. }\end{array}$ & 58 & 48.30 & 62 & 51.70 & 120 & 100.00 \\
\hline $\begin{array}{c}\text { An infected person will develop fever, body and muscle pains and, } \\
\text { yellowing of the skin and eyes. }\end{array}$ & 103 & 86.60 & 16 & 13.40 & 119 & 100.00 \\
\hline $\begin{array}{c}\text { An infected person may suffer fever and bleeding in the nose and } \\
\text { stomach }\end{array}$ & 67 & 58.30 & 48 & 41.70 & 115 & 100.00 \\
\hline $\begin{array}{c}\text { An infected person will primarily manifest allergic reactions like } \\
\text { itchiness and redness of affected skin. }\end{array}$ & 101 & 84.20 & 19 & 15.80 & 120 & 100.00 \\
\hline
\end{tabular}

Table 1.7 categorically presents the prevailing level of knowledge of health workers and barangay officials in the aspect of prevention and control. It can be gleaned that indicator numbers 1 and 3 were affirmatively considered by this group of respondent as the first two prevention and control of the disease. This corresponded to the statement stating: "Avoid wading in dirty or muddy water, if not wear boots or protective footwear," with 66 or 98.51 percent; and "Wear masks when cleaning to avoid

exposure to dust and microbes found in the air," with 34 or 50.75 percent

Consequently, the remaining two indicators were negatively assessed by this group of respondents as not one of the prevention and control of leptospirosis. These corresponded to the following: number 4, "Eradicate places that served as haven of mosquitoes," with six or 85.70 percent, also; and number 3, "Avoid being bitten by rat and cockroach,” with five or 71.40 percent.

Table 1.7. Level of Knowledge on Leptospirosis among Health Workers and Barangay Officials in the Aspect of Prevention

\begin{tabular}{|c|c|c|c|c|c|c|}
\hline \multirow{2}{*}{ Indicators } & \multicolumn{2}{|c|}{ Yes } & \multicolumn{2}{|c|}{ No } & \multicolumn{2}{|c|}{ Total } \\
\hline & Frequency & Percentage & Frequency & Percentage & Frequency & Percentage \\
\hline $\begin{array}{l}\text { Avoid wading in dirty or muddy water, if not wear boots or } \\
\text { protective footwear. }\end{array}$ & 66 & 98.51 & 1 & 1.49 & 67 & 100.00 \\
\hline $\begin{array}{c}\text { Wear masks when cleaning to avoid exposure to dust and microbes } \\
\text { found in the air. }\end{array}$ & 22 & 32.84 & 45 & 67.16 & 67 & 100.00 \\
\hline Avoid being bitten by rat and cockroach & 34 & 50.75 & 33 & 49.25 & 67 & 100.00 \\
\hline Eradicate places that served as haven of mosquitoes & 28 & 41.79 & 39 & 58.21 & 67 & 100.00 \\
\hline
\end{tabular}

Table 1.8 provides the data on the prevailing level of knowledge of the barangay residents on the prevention and control of leptospirosis. It can be noted that this group of respondents considered the following as prevention and control: number 1, "Avoid wading in dirty or muddy water, if not wear boots or protective footwear," with 112 or 94.92 percent; number 3, “Avoid being bitten by rat and cockroach," with 90 or 76.27 Percent; and number 4, "Eradicate places that served as haven of mosquitoes," with 89 or 74.79 percent. The remaining indicator, number 2, "Wear masks when cleaning to avoid exposure to dust and microbes found in the air," was not considered as prevention and control by this group of respondents with 65 or 55.08 .

Table 1.8. Level of Knowledge on Leptospirosis among Barangay Residents in the Aspect of Prevention and Control

\begin{tabular}{|c|c|c|c|c|c|c|}
\hline \multirow{2}{*}{ Indicators } & \multicolumn{2}{|c|}{ Yes } & \multicolumn{2}{|c|}{ No } & \multicolumn{2}{|c|}{ Total } \\
\hline & Frequency & Percentage & Frequency & Percentage & Frequency & Percentage \\
\hline $\begin{array}{c}\text { Avoid wading in dirty or muddy water, if not wear boots or } \\
\text { protective footwear. }\end{array}$ & 112 & 94.92 & 6 & 5.08 & 118 & 100.00 \\
\hline $\begin{array}{l}\text { Wear masks when cleaning to avoid exposure to dust and microbes } \\
\text { found in the air. }\end{array}$ & 53 & 44.92 & 65 & 55.08 & 118 & 100.00 \\
\hline Avoid being bitten by rat and cockroach & 90 & 76.27 & 28 & 23.73 & 118 & 100.00 \\
\hline Eradicate places that served as haven of mosquitoes & 89 & 74.79 & 30 & 25.21 & 119 & 100.00 \\
\hline
\end{tabular}


Table 2.1 reveals the sources of information of the health workers and barangay officials regarding the issue on leptopirosis. The table shows that this group of respondent underscored that the highest number of respondent's source of information was the news from TV, 56 or 83.58 .

Table 2.1. Sources of Information of Health Workers and Barangay Officials on Leptospirosis

\begin{tabular}{|c|c|c|c|c|c|c|}
\hline \multirow{2}{*}{ Sources } & \multicolumn{2}{|c|}{ Yes } & \multicolumn{3}{c|}{ Total } \\
\cline { 2 - 7 } & Frequency & Percentage & Frequency & Percentage & Frequency & Percentage \\
\hline Journal Article/ Medical Literature & 17 & 25.37 & 50 & 74.63 & 67 & 100.00 \\
\hline Newspaper Article & 25 & 37.31 & 42 & 62.69 & 67 & 100.00 \\
\hline News from TV & 56 & 83.58 & 11 & 16.32 & 67 & 100.00 \\
\hline Newscast from Radio & 37 & 55.22 & 30 & 44.78 & 67 & 100.00 \\
\hline City Officials & 14 & 20.90 & 53 & 79.10 & 67 & 100.00 \\
\hline Barangay Officials & 15 & 22.39 & 52 & 77.61 & 67 & 100.00 \\
\hline Doctor & 34 & 50.75 & 33 & 49.25 & 67 & 100.00 \\
\hline Nurse & 26 & 38.81 & 41 & 61.19 & 67 & 100.00 \\
\hline Information, Education, Communication Materials from DOH & 20 & 29.85 & 47 & 70.15 & 67 & 100.00 \\
\hline Traditional Midwife & 13 & 19.40 & 54 & 80.60 & 67 & 100.00 \\
\hline Information, Education, Communication Materials from LGU & 20 & 29.85 & 47 & 70.15 & 67 & 100.00 \\
\hline BHW & 16 & 23.88 & 51 & 76.12 & 67 & 100.00 \\
\hline Information Drive in School & 18 & 26.87 & 49 & 73.13 & 67 & 100.00 \\
\hline Health Volunteers & 22 & 32.84 & 45 & 67.16 & 67 & 100.00 \\
\hline Medical Students & 14 & 20.90 & 53 & 79.10 & 67 & 100.00 \\
\hline Information Drive in the Barangay Level & 18 & 26.87 & 49 & 73.13 & 67 & 100.00 \\
\hline
\end{tabular}

Table 2.2 presents the sources of Information of Barangay Residents on Leptospirosis. It can be gleaned that, news from TV topped the source of information used by this group of respondents in gaining their knowledge on the disease, leptospirosis with 96 or $80 \%$ respondents.

Table 2.2. Sources of Information of Barangay Residents on Leptospirosis

\begin{tabular}{|c|c|c|c|c|c|c|}
\hline \multirow{2}{*}{ Sources } & \multicolumn{2}{|c|}{ Yes } & \multicolumn{2}{|c|}{ No } & \multicolumn{2}{|c|}{ Total } \\
\hline & Frequency & Percentage & Frequency & Percentage & Frequency & Percentage \\
\hline Journal Article/ Medical Literature & 34 & 28.30 & 86 & 71.70 & 120 & 100.00 \\
\hline Newspaper Article & 51 & 42.50 & 69 & 57.50 & 120 & 100.00 \\
\hline News from TV & 96 & 80.00 & 24 & 20.00 & 120 & 100.00 \\
\hline Newscast from Radio & 56 & 46.70 & 64 & 53.30 & 120 & 100.00 \\
\hline City Officials & 27 & 22.50 & 93 & 77.50 & 120 & 100.00 \\
\hline Barangay Officials & 39 & 32.50 & 81 & 67.50 & 120 & 100.00 \\
\hline Doctor & 48 & 40.00 & 72 & 60.00 & 120 & 100.00 \\
\hline Nurse & 45 & 37.50 & 75 & 62.50 & 120 & 100.00 \\
\hline Information, Education, Communication Materials from DOH & 31 & 25.80 & 89 & 74.20 & 120 & 100.00 \\
\hline Traditional Midwife & 6 & 5.00 & 114 & 95.00 & 120 & 100.00 \\
\hline Information, Education, Communication Materials from LGU & 23 & 19.20 & 97 & 80.80 & 120 & 100.00 \\
\hline BHW & 31 & 26.10 & 88 & 73.90 & 119 & 100.00 \\
\hline Information Drive in School & 13 & 20.80 & 107 & 79.20 & 120 & 100.00 \\
\hline Health Volunteers & 25 & 20.80 & 95 & 79.20 & 120 & 100.00 \\
\hline Information Drive in the Barangay Level & 14 & 11.70 & 106 & 88.20 & 120 & 100.00 \\
\hline Medical Students & 19 & 15.80 & 101 & 84.20 & 120 & 100.00 \\
\hline
\end{tabular}

Table 3.1. Reactions of Health Workers and Barangay Officials on the Information Heard or Read Regarding Leptospirosis

\begin{tabular}{|c|c|c|c|c|c|c|}
\hline \multirow{2}{*}{ Reactions } & \multicolumn{2}{|c|}{ Yes } & \multicolumn{2}{|c|}{ No } & \multicolumn{2}{|c|}{ Total } \\
\hline & Frequency & Percentage & Frequency & Percentage & Frequency & Percentage \\
\hline Information received was kept to myself & 1 & 1.49 & 66 & 98.51 & 67 & 100.00 \\
\hline Information learned was shared to family members and friends & 57 & 85.07 & 10 & 14.93 & 67 & 100.00 \\
\hline $\begin{array}{l}\text { Searched for confirmation and for more information from barangay } \\
\text { officials }\end{array}$ & 24 & 35.82 & 43 & 64.18 & 67 & 100.00 \\
\hline $\begin{array}{l}\text { Searched for confirmation and more information from DOH } \\
\text { officials }\end{array}$ & 35 & 52.23 & 32 & 47.76 & 67 & 100.00 \\
\hline Felt the need for an information drive or prevention advocacy & 35 & 52.24 & 32 & 47.76 & 67 & 100.00 \\
\hline $\begin{array}{c}\text { Implemented some ways to provide protection to self and family } \\
\text { members against leptospirosis }\end{array}$ & 48 & 71.64 & 19 & 28.35 & 67 & 100.00 \\
\hline
\end{tabular}

Table 3.2 reflects the reactions of the barangay residents on the information learned regarding leptospirosis. The table shows that the first and the only reaction that this group of respondent does upon learning

regarding the disease was Information learned was shared to family members and friends. This was manifested by the magnitude of those who affirmatively responded, which is 98 or 82.35 percent. 
Table 3.2. Reactions of Barangay Residents on the Information Heard or Read Regarding Leptospirosis

\begin{tabular}{|c|c|c|c|c|c|c|}
\hline \multirow{2}{*}{ Reactions } & \multicolumn{2}{|c|}{ Yes } & \multicolumn{2}{|c|}{ No } & \multicolumn{2}{|c|}{ Total } \\
\hline & Frequency & Percentage & Frequency & Percentage & Frequency & Percentage \\
\hline Information received was kept to myself & 3 & 2.50 & 117 & 97.50 & 120 & 100.00 \\
\hline Information learned was shared to family members and friends & 98 & 82.35 & 21 & 17.65 & 119 & 100.00 \\
\hline $\begin{array}{l}\text { Searched for confirmation and for more information from barangay } \\
\text { officials }\end{array}$ & 34 & 28.30 & 86 & 71.70 & 120 & 100.00 \\
\hline $\begin{array}{l}\begin{array}{l}\text { Searched for confirmation and more information from DOH } \\
\text { officials }\end{array} \\
\end{array}$ & 43 & 35.80 & 77 & 64.20 & 120 & 100.00 \\
\hline Felt the need for an information drive or prevention advocacy & 35 & 29.20 & 85 & 70.80 & 120 & 100.00 \\
\hline $\begin{array}{c}\text { Implemented some ways to provide protection to self and family } \\
\text { members against leptospirosis }\end{array}$ & 58 & 49.15 & 60 & 50.85 & 118 & 100.00 \\
\hline
\end{tabular}

It can be gleaned in Table 4 that the health workers and barangay officials "highly concern" on three attitude statements with weighted means of $3.74,3.53$ and 3.52 corresponding to: "Awareness of the disease and its severity at the individual level;" "Over-all attitude;" and "Ability to protect self and family members," respectively. On the other hand, they were "moderately concern" on the remaining indicator with weighted mean of 3.33 with the statement of: "Adequacy of the prevention implemented by the community.' Taken as a whole, the health workers considered themselves as "highly concern" towards the issues on leptospirosis. This was manifested by the grand weighted mean of 3.53 .

Moreover, it shows that in only one attitude statement, this group of respondent was "highly concerned" corresponding to: "Ability to protect self and family members,” with weighted mean of 3.54. In the remaining

three attitude statements, the barangay residents were "moderately concerned" with weighted means of 3.45, 3.432 and 3.20 corresponding to the following: "Over-all attitude;" "Knowledge on the sickness and its worst effect to the individual level;" and "Adequacy of the prevention implemented by the community." Taken as a whole, the barangay residents were "moderately concerned" towards the issues on leptospirosis. This was indicated by the grand weighted mean of 3.41. The foregoing data indicated that somehow, the respondents were affected with the issues on leptospirosis and their major concerns were: Knowledge on the sickness and its worst effect to the individual level and Ability to protect self and family members. The health workers and barangay officials were highly concern on these but the barangay residents were moderately worried only.

Table 4. Attitude of Respondents towards the Issues on Leptospirosis

\begin{tabular}{|c|c|c|c|c|}
\hline \multirow{2}{*}{ Attitudes } & \multicolumn{2}{|c|}{ Health Workers and Barangay Officials } & \multicolumn{2}{|c|}{ Residents } \\
\hline & Weighted Mean & Interpretation & Weighted Mean & Interpretation \\
\hline Awareness of the disease and its severity at the individual level & 3.74 & $\mathrm{H}$ & 3.43 & $\mathrm{M}$ \\
\hline Ability to protect self and family members & 3.52 & $\mathrm{H}$ & 3.54 & $\mathrm{H}$ \\
\hline Adequacy of the prevention implemented by the community & 3.33 & $\mathrm{M}$ & 3.20 & $\mathrm{M}$ \\
\hline Over-all attitude & 3.53 & $\mathrm{H}$ & 3.45 & $\mathrm{M}$ \\
\hline Grand Weighted Mean & 3.53 & $\mathrm{H}$ & 3.41 & $\mathrm{M}$ \\
\hline
\end{tabular}

$\begin{array}{lll}3.51-4.00 & \text { Highly Concern } & (\mathrm{H}) \\ 2.51-3.50 & \text { Moderately Concern }(\mathrm{M}) \\ 1.51-2.50 & \text { Least Concern } & (\mathrm{L})\end{array}$

$1.0-1.50$ Not Concern at all (N)

Table 5. Prevention and Control Strategies Practiced by the Respondents against Leptospirosis and the Extent They Were Practiced

\begin{tabular}{|c|c|c|c|c|}
\hline \multirow{2}{*}{ Prevention and Control Strategies } & \multicolumn{2}{|c|}{$\begin{array}{l}\text { Health Workers and Barangay } \\
\text { Officials }\end{array}$} & \multicolumn{2}{|c|}{ Residents } \\
\hline & $\begin{array}{l}\text { Weighted } \\
\text { Mean }\end{array}$ & Interpretation & $\begin{array}{l}\text { Weighted } \\
\text { Mean }\end{array}$ & Interpretation \\
\hline $\begin{array}{l}\text { I do not step on or wash with dirty or muddy water without protection, like boots, } \\
\text { particularly during flood season }\end{array}$ & 3.45 & FP & 3.40 & FP \\
\hline I wash my hands with soap and water after I handled meat and meat preparations & 3.69 & AP & 3.68 & AP \\
\hline I wear masks when I clean to avoid my exposure to viruses brought by air & 2.89 & FP & 3.10 & FP \\
\hline $\begin{array}{l}\text { I scrutinize my hands and feet for any broken wounds or scars and I protect it with } \\
\text { cellophane or protective gear the infected part before I work at the mud or dirty } \\
\text { work area }\end{array}$ & 3.52 & AP & 3.47 & FP \\
\hline $\begin{array}{c}\text { I cook well my food and I boil my drinking water to avoid taking in leptospirosis } \\
\text { virus }\end{array}$ & 3.68 & AP & 3.74 & AP \\
\hline $\begin{array}{l}\text { I throw away wastes at the right disposal area and I avoid accumulating wastes at } \\
\text { home and in the environment }\end{array}$ & 3.80 & AP & 3.72 & AP \\
\hline I maintain cleanliness and orderliness at home and environment/work/ school & 3.70 & AP & 3.65 & AP \\
\hline I exercise good grooming and personal hygiene & 3.78 & AP & 3.65 & AP \\
\hline $\begin{array}{l}\text { I seek assistance from a professional nurse or doctor when I feel something } \\
\text { different with what I feel }\end{array}$ & 3.68 & AP & 3.61 & AP \\
\hline I seek help or consult quack doctor when I am not feeling well & 2.43 & MP & 2.43 & MP \\
\hline Grand Weighted Mean & 3.33 & FP & 3.54 & AP \\
\hline
\end{tabular}

Legend: $\quad 3.51-4.00 \quad$ Always Practiced $\quad$ (AP)

$\begin{array}{ll}2.51-3.50 & \text { Frequently Practiced (FP) } \\ 1.51-2.50 & \text { Moderately Practiced (MP) } \\ 1.00-1.50 & \text { Seldom Practiced } \quad \text { (SP) }\end{array}$

Table 5 shown Prevention and Control Strategies Practiced by the Respondents and the Extent They Were
Practiced. The foregoing data suggested that the common prevention and control strategies practiced by the three 
groups of respondents were to maintain cleanliness on the surrounding and to keep good hygiene. The health workers and barangay officials highly practiced them while the barangay residents always practiced them.

Table 6 shown comparison of the level of knowledge of the two groups of respondents on Leptospirosis and the
Extent to Which Prevention and Control against the Disease Were Practiced by Them. It found out that there were significant relationships between Etiology or Causative Organism, Common Signs and Symptoms, and Prevention and Control.

Table 6. Comparison of the Level of Knowledge of the Two Groups of Respondents on Leptospirosis and the Extent of Prevention and Control

\begin{tabular}{|c|c|c|c|c|c|}
\hline \multirow{2}{*}{ Areas } & \multicolumn{2}{|c|}{ t-value } & \multirow{2}{*}{ Pooled Variance } & \multirow{2}{*}{ df } & \multirow{2}{*}{ Evaluation } \\
\cline { 2 - 6 } & Computed & Critical & & Significant \\
\hline Etiology or Causative Organism & 2.559 & 1.653 & 0.06803 & 185 & Not Significant \\
\hline Disease Transmission & 1.444 & 1.653 & 0.05411 & 185 & Significant \\
\hline Common Signs and Symptoms & 3.796 & 1.653 & 0.061523 & 185 & Significant \\
\hline Prevention and Control & 2.662 & 1.653 & 0.119385 & 185 & S \\
\hline
\end{tabular}

Table 7 revealed the t-Table to Compare the Attitude of the Two Groups of Respondents and the Extent of Practice on the Prevention and Control of Leptospirosis. It found

out that there is significant relationships of respondent's attitude and practice on the prevention and control of Leptospirosis.

Table 7. Comparison of the Attitude of the Two Groups of Respondents and the Extent of Practice on the Prevention and Control

\begin{tabular}{|c|c|c|c|c|c|}
\hline \multirow{2}{*}{ Areas } & \multicolumn{2}{|c|}{ t-value } & \multirow{2}{*}{ Pooled Variance } & \multirow{2}{*}{ df } & \multirow{2}{*}{ Evaluation } \\
\cline { 2 - 3 } & Computed & Critical & & & \\
\hline Attitude Towards Leptospirosis & 1.129 & 1.943 & 0.24517 & 6 & Not Significant \\
\hline Extent of Prevention and Control of Leptospirosis & 0.089 & 1.734 & 0.183101 & 18 & Not Significant \\
\hline
\end{tabular}

\section{Discussions}

This study determined knowledge, attitudes, and practices of leptospirosis in selected barangays in Catbalogan City. This Analyzed as to any differences in the level of knowledge and extent of practice of prevention and control strategies. Furthermore, proposed advocacy program was proposed to improve the prevention and control strategies among residents.

Findings revealed that majority of the health workers, barangay officials and barangay residents were knowledgeable that leptospirosis was primarily caused by a bacteria. This affirms to previous study that information for the transmissions of leptospirosis to humans have become more favorable in recent years [14].

Moreover, poor knowledge of Leptospirosis implied the need for repeated health education for people especially for those with low education, as control efforts [15].

The common prevention and control strategies practiced by the three groups of respondents were to maintain cleanliness on the surrounding and to keep good hygiene. The health workers and barangay officials frequently practiced them while the barangay residents always practiced them.

This is consistent to previous study that hygienic practices determine factors such practical knowledge of health, health awareness motivation and concern for taking steps for promoting health and preventing disease [16].

The significant variation in the prevailing knowledge of the respondents on leptospirosis was traced between barangay officials and barangay residents. Hence, the prevailing knowledge on leptospirosis differed significantly between the groups. In addition, according to Wiwanitkit VDR, (2006), it found that education level was a significant parameter relating to knowledge of the respondents. The finding of the relationship between the subjects' occupation and knowledge is typified by the fact that a government officer who had the overall highest knowledge had the highest educational level [16].

Television was the major source of information among health workers, barangay officials and residents on
Leptospirosis which is essentially similar to previous study that in order to reduce the incidence and the severity of this disease, it needs to institute mass media information campaigns to warn against the risks of contamination [17]. The common prevention and control strategies practiced by the three groups of respondents were to maintain cleanliness on the surrounding and to keep good hygiene. This is significantly related to previous study that Healthy people need to practice good personal hygiene and sanitation to enable people to increase capacity, and to improved health”. It shifts above a focus on individual behavior towards a wide range of social and environmental interventions [18].

\section{Conclusion}

The three groups of respondents bore in mind the number one preventive and control strategy to avoid leptospirosis and this could be one of the information that they could share to members of the family and friends. In addition, Barwick et al. found out in order to understand disease and suggest possible strategies to control and prevent leptospirosis, therefore it needs to have basic knowledge on it [19]. On top, The primary medium that could be used for wide information dissemination is through mass media. The health workers in the RHU and local government unit must have proper information dissemination regarding Leptospirosis, highlight environmental sanitation, proper safety precautions and develop the interest of the respondents through health related magazines, listening and watching health programs etc. [20]. Moreover, Another study be conducted in other city/municipality to ascertain the level of awareness and knowledge of the community residents, thereby validating the findings of this study.

\section{Acknowledgements}

This research study would was impossible without the help of several people who humbly and kindly contributed and made time to assist in preparing for the completion of 
this study, sincerest thanks and profound gratitude to all those who made this study possible.

\section{Conflict of Interest}

The authors have no competing interests which may have influenced in writing this article.

\section{References}

[1] Christian A, Matthias, MA Richards, DC, Brouwer, KC, Cunningham CB, Eddy RS, Gilman, RH, Eduardo G, Vinetz, “ Determining Risk for Severe Leptospiros "Molecular Analysis of Environmental Surface Waters for Pathogenic Leptospira. Pmed 0030308.

[2] Heymann, D., "Control of Communicable Diseases" American Public Health Association, pp 306-309, 2008.

[3] Christian A, Matthias, MA, Richards, DC, Brouwer, KC, Cunningham CB, Eddy RS, Gilman, RH, Eduardo G, Vinetz, “ Determining Risk for Severe Leptospiros "Molecular Analysis of Environmental Surface Waters for Pathogenic Leptospira. pmed 0030308.

[4] Jansen, SI, Alpers, Frank K, Schneider T, Stark K, 2005. "Leptospirosis in Germany", Emerging Infectious Disease, vol 11, no 7, July 2005.

[5] Ganoza CA, Matthias MA, Collins-Richards D, Brouwer KC, Cunningham CB, "Determining risk for severe leptospirosis by molecular analysis of environmental surface", Waters for pathogenic Leptospira, PLoS Med 3 (8): e 308, 2006.

[6] Surveillance for Waterborne Disease and Outbreaks Associated with Recreational Water Use and Other Aquatic FacilityAssociated Health Events --- United States, 2005--2006. MMWR / 57 (SS09): 1-29. September 12, 2008.

[7] Water Sanitation and Health (WSH) Water-related diseases, WHO http://www.who.int/topics/leptospirosis/en/2003.

[8] Griffith, M.E., D.R. Hospenthal and C.K. Murray, Antimicrobial therapy of leptospirosis. Curr. Opin. Infect. Dis., 19: 533-537. 2006.
[9] Watch out for signs of leptospirosis. Republic of the Philippines Department of Health. January 2012.

[10] Thailand Flood Crisis and Disease Control Situation Report. 10 November 2011.

[11] Victoriano, AF, Lee DS, Barzaga, Nina Gloriani, Cavinta, LL, KasaiT, Limpakarnjanarat, K, Ong, BL, Gongal, GLeptospirosis in the Asia Pacific region. BMC Infectious Diseases.September 2009.

[12] Leptospirosis CPG Leptospirwww.psmid.org.ph available on pdfpedia. http://www.pdfpedia.com/download/14368/leptospirosis-cpg2010-table-of-contents-pdf.html. 2012.

[13] MGB completes geohazard map of Catbalogan City. 2011.

[14] Jansen, SI, Alpers, Frank K, Schneider T, Stark K, 2005. "Leptospirosis in Germany", Emerging Infectious Disease, vol 11, no 7, July 2005.

[15] Wiwanitkit VDR,. knowledge aspects of leptospirosis among a sample of rural villagers in the highly endemic area, Thailand, Rural \& Remote Health : 526 (Online). 2006.

[16] Deodhar NS, "Epidemiological perspective of domestic and personal hygiene in India", International Journal of Environmental Health Research, Volume 13, Supplement 001, p. S 47-S 56, 2003.

[17] Brethes B, Puech PL, Fraisse A, Dubois P, Domenech J, Bourdin P, Moreau JP, Capdevielle P, Dessouter D, Lambert M, " Pasteur de Nouméa, Nouvelle-Calédonie”, 36 (6): 436-42, 1999.

[18] Phraisuwan, Phran, S, Tharmaphornpilas, EA, Piyanit, Guharat, GS, Leptospirosis: Skin Wounds and Control Strategies, Thailand. The Healthcare Journal, p 5, ISSN 2012-4015 Issue 3 May 2010

[19] Barwick' RS., Mohammed, HO., McDonough, PL., White, ME., "Epidemiologic features of equine Leptospira interrogans of human significance, ”Preventive Veterinary Medicine, Volume 36 (2) Pages 153-167. August 1998.

[20] Wiwanitkit VDR,. knowledge aspects of leptospirosis among a sample of rural villagers in the highly endemic area, Thailand, Rural \& Remote Health : 526 (Online). 2006.

[21] ER Cachay, JM Vinetz J Postgrad. Increasing Trends of Leptospirosis in Northern India: A Clinico -Epidemiological Study. PLoS Negl Trop Dis 4 (1): e 579. 